\title{
Sovereign Wealth Funds: A Comparison of the Turkish Sovereign Wealth Fund with the World Samples
}

\author{
Fatih GÜZEL ${ }^{1}$, Melek ACAR ${ }^{1}$, Gamze ŞEKEROĞLU $^{1}$ \\ ${ }^{1}$ Departement of Business, Selcuk University
}

\begin{tabular}{l}
\hline Article Info \\
\hline Article history: \\
Received May $26^{\text {th }}, 2017$ \\
Revised June $14^{\text {th }}, 2017$ \\
Accepted June $17^{\text {th }}, 2017$ \\
\hline
\end{tabular}

\section{Keyword:}

Portfolio management

Strategic planning

The Turkish Sovereign

Wealth Fund

\begin{abstract}
Sovereign wealth funds represent unity of assets that are directly or indirectly under public control and whose investments are largely concentrated across borders. Strategic objectives of the sovereign wealth funds are accumulating income surpluses for future generations or restoring the economic order and stabilizing it over the years when volatility is intense. Turkey decided the establishment of sovereign wealth fund in 2016. In this study, firstly, information on the practices of sovereign wealth funds is given. Then, the differences between the Turkish Sovereign Wealth Fund and existing samples are revealed. As a result, criticisms have been brought about the establishment and the operation process of the Turkish Sovereign Wealth Fund. Recommendations regarding the structure of the audit system and the management organization have been presented. The Turkish Sovereign Wealth Fund is a strategic step for Turkey, if it is managed properly, transparent and reliable.
\end{abstract}

\section{Corresponding Author:}

Fatih Güzel,

Departement of Business,

Selcuk University,

Alaeddin Keykubat Campus, Konya, Selçuklu 42250, Turkey.

Email: $\underline{\text { atih guzel1990@yahoo.com }}$

\section{Introduction}

As a result of the structural transformations in economies after World War II and the rapid evolution of financial liberalization after the '80s, the importance of the economy has increased in politics and international relations. However, a robust economy, has become a significantly important weapon in the hands of the countries for being a center of power and balance in the international arena. Governments are constantly introducing new policies and new financial instruments to ensure stability alongside economic effectiveness. One of these instruments is the national wealth funds, which have different forms of practice in various countries. National wealth funds have been used for over 150 years, the real increase in the number of such funds has been experienced since 2000s. In addition to the quantitative increase, the expansion in economic size and the effective use of funds have led to intense debate in the perspective of the principles of budget unity and transparency in general. Despite this, more than 80 funds operate in more than 40 countries today. In this study, information about national wealth funds, their place in the country's economy and the Turkish Wealth Fund are given. In addition, the Turkish Wealth Fund is compared with wealth funds in other countries, and critics and suggestions are presented.

\subsection{National Wealth Funds and Purposes}

Although sovereign wealth funds have been used in more than 150 years in economy management, they have made a major leap since the 2000s. The first example of the wealth fund was created in 1854 by the Texas State Legislature in the context of private-public service. On behalf of the benefit of education and public schools, the Texas Permanent School Fund was established with \$ 2 million in grants. The sale and acquisition 
of land owned by the state are shown as a source of funds [3]. In the present sense, national wealth funds have been operating since the 1950s and becoming increasingly important players in the international money and financial system. [4].

National wealth funds are used in different ways depending on socio-economic and cultural conditions [3]. The wealth fund is a pool of assets that are in the possession or control of the state, investing heavily in the assets of other countries [8]. Another definition is the state-controlled investment institution financed by the current surplus reserves of the country [5]. Although there are more explanations in the literature, there is no generally accepted definition. For this reason, it would be more descriptive to indicate common elements of wealth funds. Features that can be counted as common elements [29]:

- National wealth funds are state owned.

- The liabilities to the other side are very limited or none at all. This increases risk appetite.

- It is managed separately from official foreign exchange reserves. Because investment objectives and areas are different from each other.

- Most or all of the fund is invested in foreign assets.

While some countries create more than one wealth fund for a single target, others use one fund to reach different targets [9]. Generally, the types of funds created by governments and the purposes they serve are listed as follows [14], [15]:

- Stabilization funds: Countries with rich natural resources are set up to isolate the budget and the economy from the volatility of commodity (usually oil) prices. Funds are created for years with high fiscal year revenues and prepared for years when there is a downward trend.

- Saving funds: Funds are established to transfer richness and wealth to future generations. Countries with rich natural resources are transferring savings funds obtained from non-renewable sources to an internationally diversified portfolio to transfer to future generations or to achieve other long-term goals.

- Reserve investment companies: Funds set up to reduce the negative carrying costs of assets to be held as reserves or to monitor higher return on investment policies and to increase the reserve profitability. Often, assets in this context preserve the reserve nature.

- Development funds: Funds set up to finance industrial socio-economic projects, such as infrastructure, or to support industrial policies that could increase the output growth of the country.

- Retirement reserve funds: The provisions made for non-cocntingent pension liabilities (from sources other than private pension contributions). These funds are the source of reserves for payments that may arise from unpredictable dates and amounts of pensions.

In summary, the main objectives of wealth funds are to assess savings effectively and in the long run, to protect the economy against crises, to reduce imbalances between economies, to provide economic prosperity to future generations and to increase the international effectiveness of the country [1] [24].

Income from balance-of-payments, official foreign exchange transactions, privatization revenues, fiscal surpluses and / or commodity issues constitute the basis for national wealth funds. [18]. In order to establish the wealth fund, there is a need for income surplus than the source selection. Depending on the nature of the surplus resource, the funds may be subject to a general classification as commodity based or non-commoditybased [32]. Commodity-based funds are based on the income generated from the exported assets. Natural gas, especially petroleum, copper and minerals are the commodities that provide resources for wealth fund. Funds that are not based on commodity are based on pension funds and foreign trade surplus, etc.

\subsection{The Place and Importance of the National Wealth Funds in the Economy}

The wealth fund will present a very high value added outcome, such as acquiring companies and managing global brands, expanding the current marketplaces, and providing competitive advantage with new information and technologies. Naturally, the return on such an investment is not limited to that. As a result of the trade made through this company, the company's customers, suppliers, and stakeholders in general terms will provide value added [26]. Another way to get a global company is to buy a company or merger. For these activities, large-scale funds are needed. One of the sources that have been actively used for economic development in the last half century is the sovereign wealth funds. Wealth funds differ because of systematic resource transfer from public savings, the ability to be a stabilization tool, and a longer-term investment horizon compared to other funds [31]. Company investments are not a goal for wealth funds, but rather a step where the fund rises above to its targets. Wealth funds aim to protect the income generated by the country's natural resources from political aspirations and conflicts and use it for the well-being of its citizens and future 
generations. In addition, overvaluation of the country's money due to the surplus of income and the reduction of the competitive advantage of the country (Dutch Disease) are also indirectly a reason for the establishment of wealth funds [30].

The past half-century and especially the 2000's, have been a period in which structural breakdowns for the world economy have experienced one after another and economic crises have affected long years. Governments have also established wealth funds as a stabilization tool, as well as taking a variety of measures to prevent or mitigate economic devastation. Sovereign wealth funds have been tasked with a breakwater mission, to prevent the volatility and crisis from worsening the economy. In Figure 1 [19], sovereign wealth funds are grouped according to the years they are established. After 2000, the increase in the number of funds is noteworthy. Two thirds of the sovereign wealth funds were established after this date.

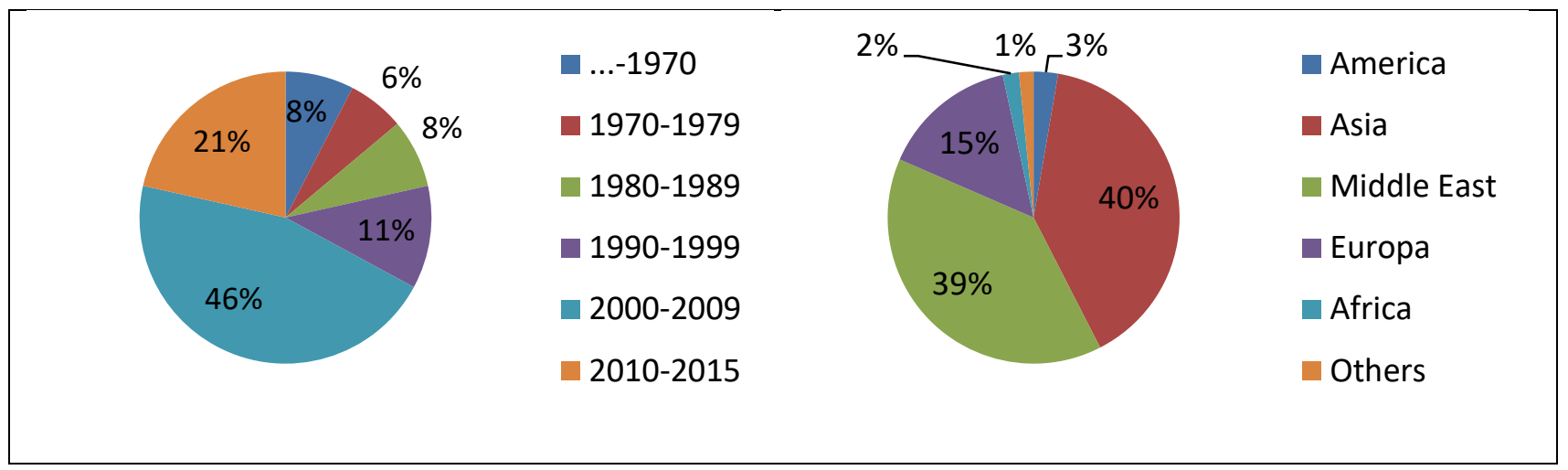

Figure 1. Sovereign Wealth Funds by Years and Region

The reason for the rapid increase in the number of sovereign wealth funds in recent years is high natural resource and commodity prices. Moreover, governments' high foreign exchange reserves and fiscal resource policies are also supporting this increase. National wealth funds are, in essence, the symbols of the latest trends in the global political economy. These funds can be expressed as a demonstration of the transfer and distribution of the economic and financial power from the US, Europe and other developed industrial countries to countries where is less, and the increasing effectiveness of governments in managing the wealth and economic power of the world today [6]. Figure 1 also shows regional distribution of wealth funds established. In general, most of the funds are in the Middle East and Asia region, which is the majority of developing countries.Sovereign Wealth Funds shows that the ownership of capital in a globalized economy is dispersed to peripheral countries. In the global financial system, countries other than Japan, USA and European countries are now playing an active role [8]. In order to measure the impact of sovereign wealth funds on global financial markets the economic magnitudes of funds should be considered [29]. Table 1 contains the top 10 funds having the largest economic size [19].

Table 1. National Wealth Funds Profile by Economic Growth (2016)

\begin{tabular}{|c|c|c|c|c|}
\hline Country & Name of Wealth Fund & Assets (Bil. US \$) & Inception & Origin \\
\hline Norway & Government Pension Fund - Global & 870.81 & 1990 & Oil \\
\hline China & China Investment Corporation & 813.8 & 2007 & Non-Commodity \\
\hline $\begin{array}{l}\text { UAE-Abu } \\
\text { Dhabi }\end{array}$ & Abu Dhabi Investment Authority & 792 & 1976 & Oil \\
\hline Suudi Arabia & SAMA Foreign Holdings & 576.3 & 1952 & Oil \\
\hline Kuwait & Kuwait Investment Authority & 592 & 1953 & Oil \\
\hline China & SAFE Investment Company & 474 & 1997 & Non-Commodity \\
\hline $\begin{array}{l}\text { China }- \text { Hong } \\
\text { Kong }\end{array}$ & $\begin{array}{l}\text { Hong Kong Monetary Authority } \\
\text { Investment Portfolio }\end{array}$ & 456.6 & 1993 & Non-Commodity \\
\hline Singapore & $\begin{array}{l}\text { Goverment of Singapore Investment } \\
\text { Corporation }\end{array}$ & 350 & 1981 & Non-Commodity \\
\hline Qatar & Qatar Investment Authority & 335 & 2005 & Oil\&Gas \\
\hline China & National Social Security Fund & 295 & 2000 & Non-Commodity \\
\hline Total (10) & & $\mathbf{5 , 5 5 5 . 5 1}$ & & \\
\hline Total (All) & & $7,409.74$ & & \\
\hline
\end{tabular}


A comparison can be made to understand the economic magnitude of sovereign wealth funds. The total economic size of the funds is about $10 \%$ of the total gross domestic product of all countries and about 10 times bigger than the Turkish economy [13]. With its growing volumes, wealth funds have faced investment allowances and management risks in the current global investment environment. Sovereign wealth funds are an important and growing investor class with one of the world's largest pools of institutional assets [17]. For this reason, the difficulties of managing their own portfolio lines are the biggest challenge for wealth funds. Figure 2 [17] shows the investment strategies of sovereign wealth funds.

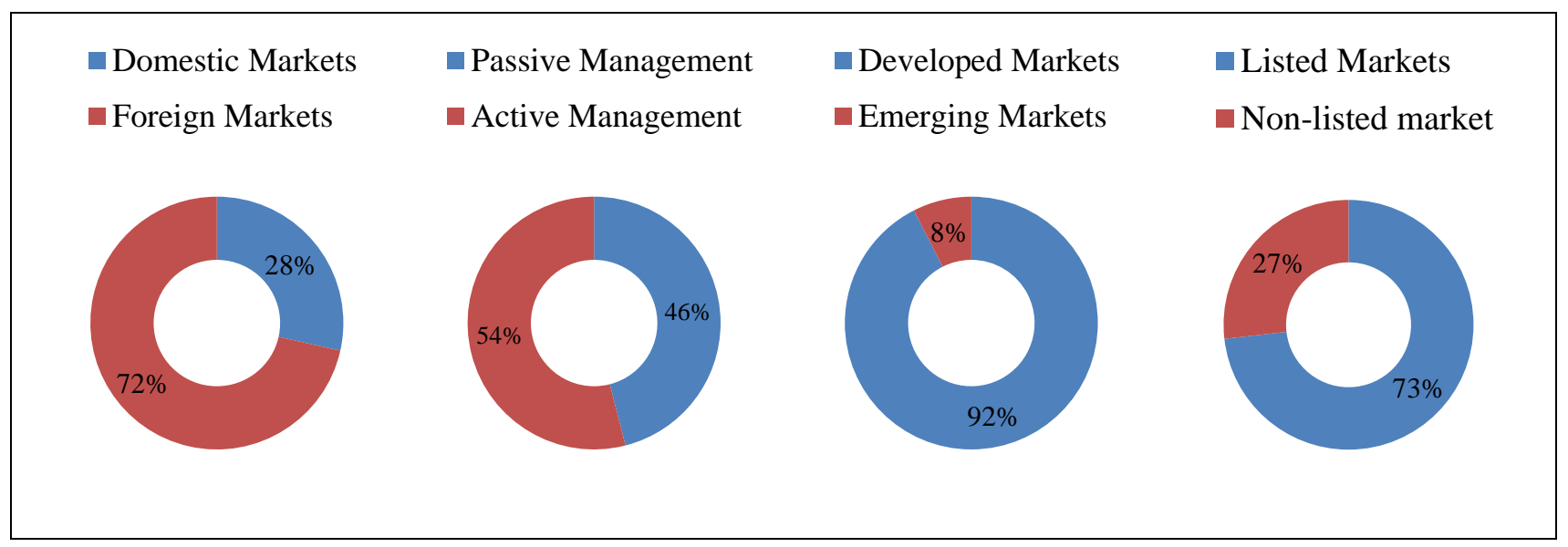

Figure 2. Sovereign Wealth Fund Asset Allocation, July 2016

As shown in Figure 2, the ratio of active and passive management strategies in the management of sovereign wealth funds is very close. There can be many reasons for this. However, long-term prospects and applications is a major cause of the rise in the rate of passive management strategy. In addition, an important point in Figure 2 is that $70 \%$ of the wealth fund is invested out of the country where the fund is located and provided resource. However, almost all of the funds were directed to the industrialized countries. It seems that the investment preferences of wealth funds favor the areas where the free float ratio is high.






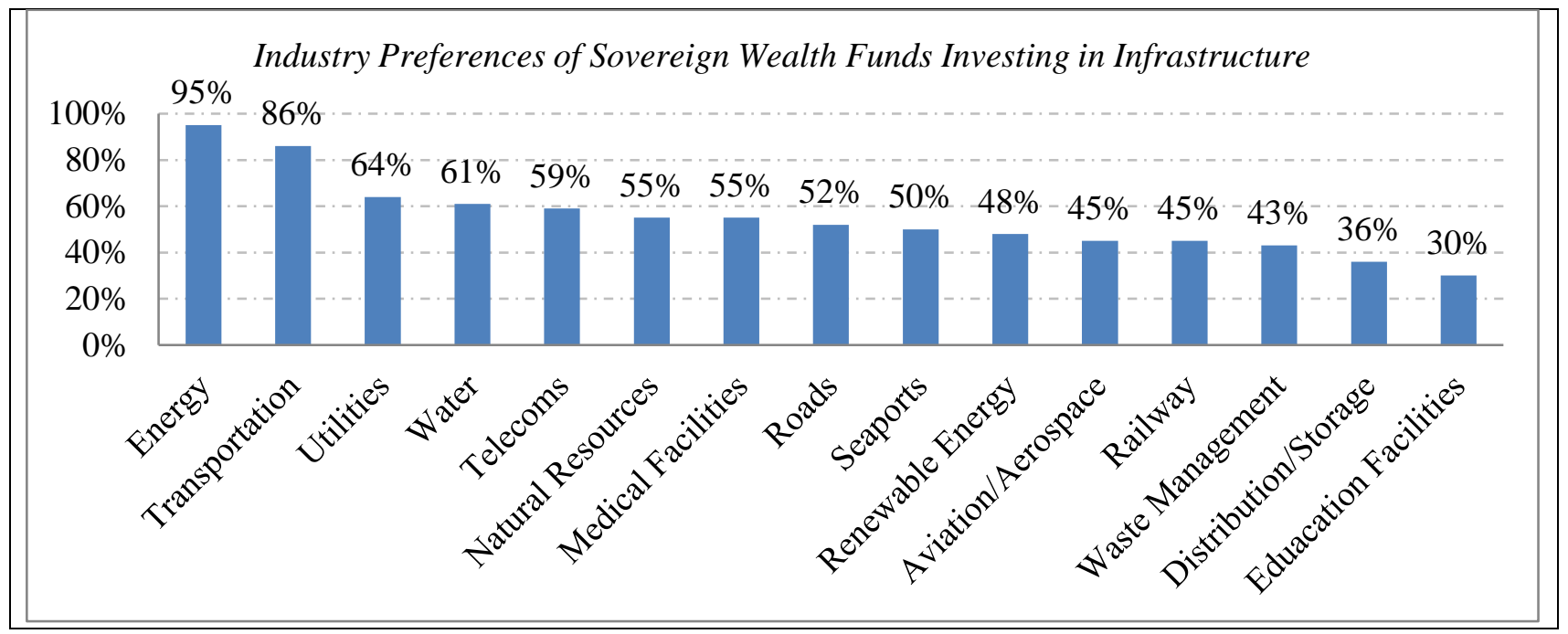

Figure 3. Investment Portfolio of Sovereign Wealth Funds (2014-2016)

Figure 3 [20] provides more detailed information on investment allocations of wealth funds between the years 2014-2016. When Figure 3 is examined, investment appetite for public stocks, fixed income instruments and hedge funds have decreased, and a steady increase in private equity corporate bonds, real estate and infrastructure investments have been experienced. However, the ratio of investors in infrastructure investments to the total number of investors in these areas is $75 \%$. This ratio is $14 \%$ in real estate, $4 \%$ in private equity and $7 \%$ in other areas. This data shows that wealth funds are used as a means of stability and development in line with the general purpose of the establishment. The increase in the number of investors operating in social infrastructure also supports this idea. More than half of wealth fund investors are more interested in investments in energy, transportation, utilities, water, communications, natural resources, health care, road and port.

Sovereign wealth funds have become quite a big economy by the end of the 2000s. The lack of an audit framework, which is caused by the fact that the funds are excluded from many regulations due to their economic size and legal structure, has been a matter of concern. In order to overcome for these concerns, The International Working Group of Sovereign Wealth Funds has been established as a result of negotiations with global groups such as the IMF, the FED and the G20 countries. In 2009, the institution changed its name as International Forum of Sovereign Wealth Funds. In 2008, the Institution published the "Generally Accepted Principles and Practices" statement known as "Santiago Principles" in the context of corporate governance and risk management [25]. The Forum will contribute to the development and maintenance of an open and stable work environment and thus support the four guiding objectives underlying the Santiago Principles. These objectives are [12]:

- Assisting in the free circulation of capital, investments and the preservation of the stability of the global financial system,

- To fulfill the valid, explanatory and regulatory requirements of the invested country,

- Invest in risk and return based on economic and financial factors,

- To have a transparent and sound management structure that ensures adequate operational control, risk management and accountability.

The Santiago principals are based on volunteerism and are not internationally binding. However, it is a prerequisite for entry into US and European markets. Therefore, funds strive to comply with the relevant principles [8], [21]. All funds within the sovereign wealth fund do not comply equally with the Santiago Principles. For this reason, an index has been developed by Carl Linaburb and Michael Maduell in the Sovereign Wealth Fund Institute (SWFI), a pioneer in research and documentation on wealth funds, to measure the level of information sharing with the public [11]. The index is referred to by its founders and is known as the Linaburg-Maduell Index. The index is used globally, is included in annual reports of funds, and functions as a standard global benchmarking tool. The index consists of 10 items and each item is worth one point [16]. 


\section{Turkish Sovereign Wealth Fund}

The Turkish Wealth Fund (TWF) was established on the date of publication in the Official Gazette on August 26, 2016 by the Law No. 6741 "Amendment of the Law on the Establishment of the Turkish Wealth Fund Management Joint Stock Company". Information on TWF's purpose, scope, management and supervision, resources and economic size are given below.

\subsection{The Turkish Wealth Fund's Purposes and Field of Activity}

The aims of TWF [23] are:

- To contribute to the diversity and depth of the capital market instruments,

- To bring in the assets belonging to the public in the country into the economy,

- To provide foreign investment,

- To establish and manage subsidiary funds in order to participate in strategic and large-scale investments.

With the establisment of the fund, in addition to the above mentioned items, the law draft submitted to the Grand National Assembly of Turkey (TGNA) with not being included in the text of the law and legislative intention [22], it is targeted that:

- An additional $1.5 \%$ increase in growth rate over the next 10 years,

- Acceleration of growth and deepening of capital markets,

- Dissemination of the use of Islamic finance instruments,

- Additional employment for hundreds of thousands of people with investments to be made,

- Ensuring that domestic players are supported by capital and projects in technology-intensive strategic sectors such as defense, aviation and software,

- Financing of large infrastructure projects without raising public sector debt,

- Increasing the share of participation finance sector,

- Direct investment in strategic sectors such as natural gas and oil, which are important for Turkey in order to ensure security of supply, without being subject to legal and bureaucratic restrictions.

In addition, the fund has been assigned to be an instrument to contribute to overcoming the structural problems of the Turkish economy and to enhance the effectiveness of Turkey at the international level. Within the scope of Article 2 of Law No. 6741, the transactions that can be made by TWF considering the liquidity, investment, risk and return preferences in order to reach its targets are as follows:

- Purchase and sale of the shares of domestic and foreign companies, the shares of the issuers in Turkey and abroad and the debt instruments, the capital market instruments issued based on precious metals, fund participation shares, derivative instruments, lease certificates, real estate certificates, custom designed foreign investment instruments and other instruments,

- All kinds of money market transactions,

- Evaluation of real estate, rights based on real estate and all kinds of immaterial rights,

- All kinds of project development, project based resource creation, external project loan provision and other methods of providing resource,

- All kinds of commercial and financial activities are carried out at national and international primary and secondary markets. The company may participate with national investments to the investments to be made in other countries and / or foreign companies in the international arena.

\subsection{Management and Supervision of the Turkish Wealth Fund}

The TWF is directly linked to the Prime Minister for management. The president, members and general manager are appointed by the Prime Minister in the board of directors consisting of at least five members. As the appointment criteria, the president, members and general manager are required to have experience more than five years in at least one of the fields of economy, finance, law, finance and banking.

Sub-funds within the TWF will be managed within the framework of a three-year strategic investment plan, which is prepared by the company and the board of directors and is in force with the approval of the Council of Ministers. The organization, structure, functioning, management and transactions of TWF related funds shall be determined within the provisions of TWF's internal regulations and company's articles of association. [23]. The Board of directors meetings can be held with the absolute majority of the total members. The 
decisions of the board of directors may be taken by the absolute majority of the members attending the board meetings [1].

TFV management has the obligation to comply with the corporate governance principles and regulations under the Capital Markets Law No. 6362. TWF and its sub-funds will be subject to independent audit. Financial statements of the TWF, sub-funds, company and affiliated companies will be audited by at least three central auditors appointed by the Prime Minister. These auditors are specialized in capital markets, finance, economy, treasury, banking and development. Prepared report as a result of the audit is presented to the Council of Ministers by the end of June every year and is examined annually in October by the Planning and Budget Commission of the TGNA through audit reports [23]. With this arrangement, a triple control mechanism is ensured.

TWF management is structured as a joint stock company in the private company status. It is subject to the Law on the Chamber of Accounts, the Civil Servants Law, the Public / State Procurement Law, the laws on privatization, the laws of the State Economic Enterprises (SEEs), and the law on the Supervision of the TGNA on Funds and SEEs. In addition, the fund is exempt from VAT and not subjetct to the Capital Markets Law, the Competition Law and income tax, corporation tax, real estate tax, stamp tax, bank and insurance transaction tax, resource utilization support fund withdrawal and some transactions [1].

\subsection{Resources and Economic Size of TWF}

The capital of the TWF management company, which is TL 50 million, was provided by the Privatization Fund. Full paid capital stocks belong to the Privatization Administration. On 24 January 2017, TL 3 billion belonging to the Industrial Support Fund was transferred to TWF on condition of reimbursement for three months' usage. On January 31, 2017, certain entities and treasury-owned real estate were transferred to the wealth fund [2]. Table 2 lists the companies transferred to TWF.

Table 2. Transferred Corporations to the Turkish Wealth Fund (February 2017)

\begin{tabular}{|c|c|c|c|}
\hline Corporations & \begin{tabular}{|l} 
Treasury Shares \\
(Transferred assets)
\end{tabular} & Capital & Assets \\
\hline T.R. Ziraat Bankası Inc. & $100,00 \%$ & TL 5.100.000.000 & TL $371.881 .925 .000^{1}$ \\
\hline Halkbank Inc. & $51,11 \%$ & TL 1.250.000.000 & TL 237.726.267.000 \\
\hline $\begin{array}{l}\text { BOTAS Petroleum Pipeline } \\
\text { Corporation }\end{array}$ & $100,00 \%$ & TL 4.145.000.000 & TL 20.312.158.318 \\
\hline $\begin{array}{ll}\text { Turkish } & \text { Petroleum } \\
\text { Corporation } & \\
\end{array}$ & $100,00 \%$ & TL 3.000.000.000 & TL 10.981.613.631 \\
\hline Turkish Post Inc. & $100,00 \%$ & TL 981.530.194 & TL 3.980.492.6372 \\
\hline Borsa Istanbul Inc. & $73,60 \%$ & TL 423.234 .000 & TL 7.873.409.000² \\
\hline Turkish Airlines Inc. & $49,12 \%$ & TL 1.380 .000 .000 & TL 47.638.000.000² \\
\hline $\begin{array}{l}\text { Turk Satellite Communication } \\
\text { Cable TV and Operation Inc. }\end{array}$ & $100,00 \%$ & TL 1.474.816.334 & TL $1.980 .870 .355^{1}$ \\
\hline Turk Telecom Inc. & $31,68 \%(6,68 \%)$ & TL 3.500.000.000 & TL 26.874.451.000 \\
\hline Eti Mine Works & $100,00 \%$ & TL 600.000 .000 & TL 3.037.800.0002 \\
\hline Caykur & $100,00 \%$ & TL 1.492 .400 .000 & TL 2.072.400.0002 \\
\hline TOTAL & & $\begin{array}{l}\text { TL 23.346.980.528 } \\
(=\$ 6.342 .909 .294)\end{array}$ & $\begin{array}{r}\text { TL 734.359.386.941 } \\
(=\$ 199.510 .809 .319)\end{array}$ \\
\hline $\begin{array}{l}1=2016 \\
2=2015\end{array}$ & & & \\
\hline
\end{tabular}

In addition to the companies listed in Table 2, all winning games licenses owned by the National Lottery are transferred to the TWF. Authorities of the Turkish Jockey Club for domestic and international joint bets and real estates owned by them are also transferred to TWF. In addition to this, the allocations on 46 public buildings in Antalya, Aydın, Isparta, Istanbul, İzmir, Kayseri and Muğla totaling 2,292,815 square meters were canceled and transferred to TWF [2]. At present, the wealth fund has TL 23 billion of equity capital and 
reached TL 734 billion in asset size. With an asset size of approximately \$ 196 billion and a large number of real estate, TWF can be seen as one of the attention grabbingfunds among world wealth funds.

\section{Comparison of The Turkish Wealth Fund with Other Wealth Funds}

TWF is different from the world's examples both quantitative and qualitatively. TWF will use the securitization of publicly owned companies, public properties, revenues from privatization transactions, and transactions to be carried out in the capital market as resources. However, when we look at the applications in the world in general, it is seen that the source of wealth funds is the budget surplus, trade or commodity export revenues such as oil, mineral resource, natural gas. In terms of the resources, it is obvious that TWF follows a different path from the examples in the world. But the lack of capital and technology are the biggest problems experienced by developing countries. TWF is a major capital resource. The Fund will support technologyintensive sectors such as defense, aviation and software, and will provide an opportunity to increase competitive advantage by providing high know-how with international partnerships and to raise the country's upper middle income to upper income level [10].

Wealth funds are generally established for saving. The goal is to allocate resources in the years when economic welfare is experienced, and to support prosperity in the years when it is reduced. Another objective is to transfer income from resources will be exhausted future generations and to share it with them. TWF will serve as an inexpensive outsourcing tool for the financing of very large-scale investments to be made [27]. Clearly, TWF does not have the essence of wealth funds, because it carries expenditure fund features instead of a savings fund. However, among the targets, the diversity of instruments in the capital markets and the importance given to Islamic finance applications, both the fund and the private sector will be able to reach cheaper financing sources at national and international scale. In addition, the fact that Islamic financial institutions in Turkey can directly reflect national transactions on international market shares will increase the efficiency of the sector. It is a good decision to support this sector which has not received open support by public until today. However, it is a fact that these goals do not match with the practice in the world. Supporting Islamic finance by increasing the share of participation banks is not among the objectives any other wealth fund.

In terms of auditing, TWF differs from other funds in the world. Given the international framework is generally true as the application that independent audit firms take part in the supervision. However, supervision with three auditors appointed by the Prime Minister is of concern in two respects. The first is that both the management and the control mechanism are managed from the same hand, which is an application open to misconduct. The second is that the number of central supervisory staff is at least three. The adequacy of a three-person team should be questioned to supervise an enormous economic organization of TL 734 billion. Moreover, the fact that these supervisory auditors are public servants contradicts the independence principle of the supervisor. Instead of leaving the audit duty of the Fund to the TGNA and sending the audit reports directly to the TGNA, it is a more correct approach to leave the audit to the Chamber of Accounts [28].

The most criticized point is contrariness to the principle of unity of the budget. In the general applications of wealth funds in different countries income is transferred to the fund, while TWF has income generating sources directly. The negative effects of the multi-budget system were evident at the beginning of the 1980s, 1990s and 2000s, and the effects of separately funded funds in the crisis have been discussed for many years. The disadvantages of this system are the reduction of income of the central budget, the loss of expenditure priorities [32]. At this point, it is vital that the fund management should constitute and implement the threeyear strategic investment plan in a budget-supporting manner.

Companies with very different qualities from different sectors have been transferred to TWF as resource. This situation differs from other wealth fund applications. The fact is that the Fund has unfair competitive advantage over the market forces during the activities it will undertake when considering the diversity of activities and the exempted laws. For example, where will the banks in the portfolio be located in the regulations of the Banking Regulation and Supervision Agency (BRSA), how will the Capital Market Law be operated in the process of securitization of assets and how will their income be taxed? There are serious gaps in terms of legal regulations [7]. It is extremely important that the relevant legal regulations should be made as soon as possible. 


\section{Conclusion}

Wealth funds, established for a wide variety of purposes, are generally endeavoring to support the economy and increase the level of prosperity. Regardless of the level of development, many countries are benefiting from wealth funds. Turkey has established a sovereign wealth fund in order to provide funds for strategic and large scale investments in general. The companies that are transferred to the fund are the locomotive firms of their sectors and make profit in large quantities. Therefore, transferred assets and companies can be considered as the most valuable companies of Turkey. The Fund may provide a high amount of credit from the market under appropriate conditions by showing these assets as collateral. In addition to cash return gained from these credits through effective evaluation of market conditions, it is possible to obtain value added such as diversification of market and customer portfolio with international investments to be made.

However, the current regulations concerning the selection and supervision of the management cadre are the greatest handicap in terms of the effectiveness of the fund and its independent implementation of its policies in line with macroeconomic developments. The fact that the fund management is seen as a unit attached to the executive authority is the greatest danger in terms of fund independence, success and impartiality. Independence is an important threshold for success. At this point, at least one of the management and supervision mechanisms seems to have been passed to the Assembly by the Prime Minister.

Besides the establishment and supervision of the Fund, management at international standards is important in terms of the enforcement of the investments to be carried out and the markets in which they can be influenced. The press conference and the written explanations emphasize the adoption of the Santiago Principles. This has a key prefix for entry into European and US markets, where value added is high. With the transparency and professional management to be provided in accordance with the principles, the fund will be able to achieve its stated objectives.

Turkey has a great opportunity with TWF. In today's turbulence macroeconomic environment, a structure that will support the economy has become compulsory. However, the fact that such a large economic organization operates separate from treasury may be regarded as a deviation from the budgetary unity which is one of the cornerstones of economic stability. As a result, Turkey's international voice may be louder, while using the resources efficiently it has. The Turkish Wealth fund's activities in the free market, not in the midst of political conflicts, have a vital importance to the success of the fund.

\section{References}

[1] İ. Özkul, «11 soruda tüm yönleriyle Türkiye Varlık Fonu» 10 Şubat 2017. [Online]. Available: http://www.dunya.com/ekonomi/11-soruda-tum-yonleriyle-turkiye-varlik-fonu-haberi-349431. [Date of Access: 10 February 2017].

[2] Official Gazette, «5 Şubat 2017 Tarihli ve 29970 Sayll Resmî Gazete - Mükerrer» 5 February 2017. [Online]. Available: http://www.resmigazete.gov.tr/eskiler/2017/02/20170205M1.htm. [Date of Access: 15 February 2017].

[3] M. N. J. Firzli ve J. M. Franzel, «Non-Federal Sovereign Wealth Funds in the United States and Canada: Public Asset Accumulation and Investment in Developed Economies» Revue Analyse Financière, no. 52, pp. 6-8., September 2014.

[4] S. Willson, «IMF Survey: Wealth Funds Group Publishes 24-Point Voluntary Principles» 15 October $2008 . \quad$ [Online]. Available: https://www.imf.org/en/News/Articles/2015/09/28/04/53/sonew101508b. [Date of Access: 20 February 2017].

[5] S. Akbulak ve Y. Akbulak, «Ulusal Varlık Fonlarl» Marmara Üniversitesi I.I.I.B.F. Dergisi, cilt 25, no. 2, pp. 237-262., 2008.

[6] E. M. Truman, «Sovereign Wealth Funds: Threat or Salvation?» Washington: Peterson Institue for International Economics, 2010.

[7] N. Saygılıŏlu, «Türkiye Varlık Fonu Hakkında Akla Takılan Sorular» 8 Şubat 2017. [Online]. Available: http://www.dunya.com/kose-yazisi/turkiye-varlik-fonu-hakkinda-akla-takilansorular/349066. [Date of Access: 8 Şubat 2017].

[8] H. Aykın, «Ulusal Refah Fonlarl:Risk mi, Firsat mı?» 2011. [Online]. Available: http://www.sde.org.tr/tr/newsdetail/-ulusal-refah-fonlari-risk-mi-firsat-mi-analizi/2725. [Date 
of Access: 20 Şubat 2017].

[9] I. Petrova, J. Pihlman, P. Kunzel ve Y. Lu, «Investment Objectives of Sovereign Wealth Funds : A Shifting Paradigm» January 2011. [Online]. Available: https://www.imf.org/external/pubs/ft/wp/2011/wp1119.pdf. [Date of Access: 17 January 2017].

[10] Ş. Manukyan, «Varlık Fonu Dinamikleri Nelerdir? Global Örnekler» 10 Şubat 2017. [Online]. Available: $\quad$ http://www.dunya.com/kose-yazisi/varlik-fonu-dinamikleri-nelerdir-globalornekler/349407. [Date of Access: 10 Şubat 2017].

[11] M. Ercan, «Ülke varlı fonlarının önemi ve yapısı» 7 Eylül 2013c. [Online]. Available: http://www.radikal.com.tr/yazarlar/metin-ercan/ulke-varlik-fonlarinin-onemi-ve-yapisi1149687/. [Date of Access: 13 Şubat 2017].

[12] IFSWF, «Establishment of the International Forum of Sovereign Wealth Funds» 6 April 2009. [Online]. Available: http://www.ifswf.org/santiago-principles-landing/kuwait-declaration. [Date of Access: 28 January 2017].

[13] The World Bank, «GDP Ranking» 1 February 2017. [Online]. Available: http://data.worldbank.org/data-catalog/GDP-ranking-table. [Date of Access: 8 February 2017].

[14] IMF, «Global Financial Stability Report» October 2007. [Online]. Available: https://www.imf.org/External/Pubs/FT/GFSR/2007/02/pdf/text.pdf. [Date of Access: 2 February 2017].

[15] IMF, «IMF Survey: IMF Intensifies Work on Sovereign Wealth Funds» 4 March 2008. [Online]. Available: https://www.imf.org/en/News/Articles/2015/09/28/04/53/sopol03408a. [Date of Access: 3 February 2017].

[16] SWFI, «Linaburg-Maduell Transparency Index» 2017c. [Online]. Available: http://www.swfinstitute.org/statistics-research/linaburg-maduell-transparency-index/. [Date of Access: 21 February 2017].

[17] IFSWF, «New Challenges, Private Markets: Sovereign Wealth Funds' Changing Investment Strategies» November 2016. [Online]. Available: http://www.ifswf.org. [Date of Access: 21 February 2017].

[18] IMF, «Setting up a Sovereign Wealth Fund: Some Policy and Operational Considerations» $\begin{array}{lll}\text { August } 2009 . & \text { [Online]. }\end{array}$ https://www.imf.org/external/pubs/ft/wp/2009/wp09179.pdf. [Date of Access: 15 January 2017].

[19] SWFI, «Sovereign Wealth Fund Rankings» 2017a. [Online]. Available: http://www.swfinstitute.org/sovereign-wealth-fund-rankings/. [Date of Access: 21 February 2017].

[20] PREQIN, «Sovereign Wealth Funds Investing in Infrastructure» May 2016. [Online]. Available: https://www.preqin.com/docs/newsletters/ra/Preqin-Real-Assets-Spotlight-May2016.pdf. [Date of Access: 1 March 2017].

[21] IWG, «Sovereign Wealth Funds: General Accepted Principles and Practices» October 2008. [Online]. Available: http://www.ifswf.org/sites/default/files/santiagoprinciples_0_0.pdf. [Date of Access: 8 February 2017].

[22] TGNA, «Türkiye Varlı Fonu Kurulması ile Bazı Kanun ve Kanun Hükmünde Karanamelerde Değişiklik Yapılmasına Dair Kanun Tasarısı» 1 Ağustos 2016. [Online]. Available: http://www2.tbmm.gov.tr/d26/1/1-0750.pdf. [Date of Access: 2 Mart 2017].

[23] Official Gazette, «Türkiye Varlı Fonu Yönetimi Anonim Şirketinin Kurulması İle Bazı Kanunlarda Değişiklik Yapılmasına Dair Kanun» 26 Ağustos 2016. [Online]. Available: http://www.resmigazete.gov.tr/eskiler/2016/08/20160826-1.htm. [Date of Access: 4 Şubat 2017].

[24] SWFI, «What is a SWF?» 2017b. [Online]. Available: http://www.swfinstitute.org/sovereignwealth-fund/. [Date of Access: 23 February 2017]. 
[25] IFSWF, «What is the IFSWF?» 2017. [Online]. Available: http://www.ifswf.org. [Date of Access: 22 Şubat 2017].

[26] M. Ercan, «Türkiye küresel büyüme fonu-2» 31 Ağustos 2013b. [Online]. Available: http://www.radikal.com.tr/yazarlar/metin-ercan/turkiye-kuresel-buyume-fonu-2-1148616/. [Date of Access: 12 Şubat 2017].

[27] O. Arolat, «Dünyada Varlık Fonlarındaki Amaç Bugünün Zenginliğini Yarınlara Bırakmaktır Ya Bizimki...» 8 Şubat 2017. [Online]. Available: http://www.dunya.com/kose-yazisi/dunyadavarlik-fonlarindaki-amac-bugunun-zenginligini-yarinlara-birakmaktir-ya-bizimki/349084.

[Date of Access: 8 Şubat 2017].

[28] A. Arslan, «Varlik Fonu Nasıl Denetlenecek?» 8 Şubat 2017. [Online]. Available: http://www.dunya.com/kose-yazisi/varlik-fonu-nasil-denetlenecek/349078. [Date of Access: 8 Şubat 2017].

[29] R. Beck ve M. Fidora, «The Impact of Sovereign Wealth Funds on Global Financial Markets» July 2008. [Online]. Available: https://www.ecb.europa.eu/pub/pdf/scpops/ecbocp91.pdf. [Date of Access: 4 February 2017].

[30] T. Belli, «Varlık Fonu'na Neden İhtiyaç Duyuldu?» 9 Şubat 2017. [Online]. Available: http://www.dunya.com/kose-yazisi/varlik-fonuna-neden-ihtiyac-duyuldu/349233. [Date of Access: 9 Şubat 2017].

[31] M. Ercan, «Türkiye küresel büyüme fonu» 24 Ağustos 2013a. [Online]. Available: http://www.radikal.com.tr/yazarlar/metin-ercan/turkiye-kuresel-buyume-fonu-1147534/. [Date of Access: 11 Şubat 2017].

[32] M. Eğilmez, «Kendime Yazılar: Varlık Fonu» 25 Ağustos 2016. [Online]. Available: http://www.mahfiegilmez.com/2016/08/varlk-fonu.html. [Date of Access: 7 Şubat 2017]. 